\author{
Л.М. Сакович ${ }^{1}$, С.І. Глухов ${ }^{2}$, О.С. Бабій ${ }^{2}$, А.О. Гальоса ${ }^{3}$ \\ ${ }^{1}$ Iнститут спечіального зв 'язку та захисту інформації \\ Національного технічного університету України \\ “Київський політехнічний інститут ім. I. Сікорського”, Київ \\ ${ }^{2}$ Київський начіональний університет ім. Т. Шевченка, Київ \\ ${ }^{3}$ Коледж інженерії та управління Національного Авіаційного Університету, Київ
}

\title{
МЕТОДИКА ФІЗИЧНОГО ДІАГНОСТУВАННЯ ЦИФРОВИХ ПРИСТРОЇВ ОБ'ЄКТІВ РАДІОЕЛЕКТРОННОЇ ТЕХНІКИ
}

У статті представлена методика фізичного діагностування ичифрових пристроїв об'єктів радіоелектронної техніки, яка трунтується на використанні енергодинамічного, енергостатичного та електромагнітного методів діагностування. Вона передбачає поодиноке або комплексне застосування зазначених методів, щзо залежить від вірогідності діагнозу, яка вимагається. Остання зумовлена важливістю об'єкта радіоелектронної техніки, а також випадками, в яких неможливо прийняти рімення про технічний стан при використанні якогось одного з методів діагностування. Використання даної методики спрямовано на визначення технічного стану з вірогідністю не нижче 0,95, а ї̈ застосування на першому рівні системи технічного обслуговування і ремонту радіоелектронної техніки дозволить проводити визначення реального технічного стану при глибині діагностування цииррового пристрою (радіоелектронного компоненту), щзо призведе до зменшення логістичної складової доставки цифрових пристроїв у ремонтні органи та в зворотному напрямку. Застосування даної методики доцільно в роботі автоматизованої системи технічної діагностики радіоелектронної техніки.

Ключові слова: радіоелектронна техніка, циирові пристрої, радіоелектронні компоненти, технічний стан, прогнозування, інтелектуальна система діагностування.

\section{Вступ}

Постановка проблеми. Надійність радіоелектронної техніки (РЕТ), яка відіграє важливу роль в житті суспільства, залежить від якості елементної бази та можливостей діагностичного забезпечення. Проблема надійності РЕТ завжди була актуальною та загострюється сьогодні в умовах постійно зростаючих вимог до показників надійності, оскільки більшість об'єктів відпрацювали призначений ресурс, а діагностичне забезпечення [1] стає непристосованим до якісного проведення діагностування та завчасного упередження відмов.

Розглянемо детальніше основні причини такого стану.

Першою причиною $є$ економічні чинники, 3 яких оновлення парку дорогою РЕТ здійснюється повільно, це обумовило прийняття рішень щодо продовження призначених термінів експлуатації, які зазвичай складають $10-15$ років.

Друга причина такого стану полягає у тому, що для діагностування більшості об’єктів, які експлуатуються в Україні та виготовлені на елементній базі третього та четвертого поколінь, починаючи з 80-х років, використовується обладнання для проведення тестового або функціонального діагностування [2-
4]. Визначення технічного стану проводиться на основі порівняння еталонних та отриманих сигнатур. Останні будуть відповідати еталонним у різних випадках, яким відповідають різні рівні стану (виродження) кристалів інтегральних мікросхем (IMC). Оскільки сигнали у цифровій техніці являють собою двійкові комбінації, на виході інтегральних схем, кристали яких знаходяться у передкритичному стані, буде сформована комбінація, яка відповідає справному стану.

Після проведення діагностування цифрового пристрою (ЦП) методами функціонального діагностування через непередбачуваний час він виходить зі строю, що негативно впливає на коефіцієнт готовності (Кг) як комплексний показник надійності всього об'єкту.

Аналіз останніх досліджень і публікацій. Тому постало питання розробки та використання інших методів діагностування [5-7], які дозволять 3 достатньо високою вірогідністю на основі значень діагностичних параметрів (ДП) визначити реальний технічний стан. 3 цієї причини були проведені форсовані випробування радіоелектронних компонентів (РЕК) на надійність, в результаті яких були отримані залежності ДП від часу для кожного методу діагностування [8-9]. 
Порівняння фактичних значень ДП, отриманих при проведенні діагностування у період експлуатації об'єктів РЕТ, з отриманими при форсованих випробуваннях, дозволяє з високою вірогідністю визначати реальний технічний стан ЦП, прогнозувати його, а також визначати залишковий ресурс ЦП.

У роботах [10-12] було запропоновано здійснення функцій технічної діагностики, а саме, визначення технічного стану ЦП, локалізацію несправних РЕК 3 їх складу, прогнозування технічного стану (TC) з використанням інтелектуальної системи діагностики (ICД), яка є елементом центру обробки діагностичної інформації (ДІ), що представляє собою другий рівень системи технічного обслуговування i ремонту (СТOіP).

Важливо відмітити те, що для здійснення зазначених функцій ІСД вирішує наступні завдання:

- вибору методів діагностування в залежності від вірогідності, яка вимагається;

- керування процесом діагностування, отримання, збору, зберігання ДІ;

- корегування залежностей ДП від часу, отриманих у ході діагностування;

- розрахунку міжперевірочних інтервалів;

- визначення залишкового ресурсу.

Вирішення перелічених завдань можливо за умови оснащення першого рівня СТОіР - рівня об’єкту пристроями діагностування (ПД), кожний $з$ яких реалізує відповідний метод діагностування: енергодинамічний (ПД-1), енергостатичний (ПД-2), електромагнітний (ПД-3).

Виконання зазначених завдань 3 використанням методів фізичного діагностування 3 метою забезпечення достатньо високої вірогідності діагнозу та прогнозу потребує розробки методики фізичного діагностування ЦП об’єктів РЕТ, що і $є$ метою даної статті.

\section{Виклад основного матеріалу}

В залежності від вірогідності, яка вимагається, а також у ситуаціях невизначеності ТС при використанні будь-якого одного метода діагностування, можна застосовувати два або три метода.

Діагностування одного ЦП можна проводити одним ПД, який реалізує перший метод, в цей час діагностування другого ЦП проводити другим ПД, а діагностування третього ЦП проводити третім ПД. За відсутністю сумнівів у визначенні ТС кожного ЦП одним методом, немає необхідності проводити діагностування ЦП іншим методом.

При такій схемі наявність трьох ПД дозволяе проводити діагностування одразу трьох ЦП, тобто здійснювати його паралельно, що значно зменшує середній час діагностування, і як наслідок, збільшує коефіцієнт готовності. У ситуаціях, коли з різних причин виникає необхідність проведення діагносту- вання одного ЦП різними методами, а також при діагностуванні ЦП блоків об’єктів критичної інфраструктури, час діагностування буде збільшений.

У випадках, коли вимагається максимальна вірогідність, діагностування проводиться трьома методами, що дозволяє досягнути рівня 0,99995.

У випадках, коли два $з$ трьох методів визначають ТС як справний, а третій як несправний, приймається рішення за мажоритарним принципом. В окремих випадках передбачається проведення повторної перевірки, що передбачено у алгоритмі, який наводиться нижче.

Рішення щодо комплексного використання методів діагностування сумісно з результатами форсованих випробувань РЕК на надійність дозволили 3 достатньо високою ймовірністю упереджувати поступові відмови, пов'язані з виродженням кристалів IMC. Це призводить до збільшення середнього наробітку на відмову блоку та збільшенню коефіцієнту готовності об'єкта РЕТ.

Крім того, для локалізації несправного РЕК зі складу ЦП, який вийшов зі строю, запропоновано оснащення першого рівня пристроєм діагностування ПД-4 (рис. 1).

Це дозволить визначати несправність на глибині не відновлювального елементу на першому рівні СТОіР, що відрізняе іiі від існуючої СТОіР, в якій локалізація несправних РЕК здійснювалась на другому рівні СТОіР, розташованому від першого на відстанях від сотні до тисячі кілометрів (рис. 1), що значно збільшувало середній час відновлення за рахунок логістичної складової. Це зумовлено відсутністю ПД та засобів ремонту на першому рівні СТОіР, які дозволять проводити діагностування на глибині РЕК та поточний ремонт ЦП шляхом заміни несправних РЕК.

Рішення щодо здійснення поточного ремонту на першому рівні $\epsilon$ новим. Воно дозволить значно зменшити середній час відновлення та збільшити коефіцієнт готовності як комплексний показник надійності.

Крім того, таке рішення дозволить підвищити укомплектованість комплекту запасних інструментів та приладдя - одиночний (ЗІП-О) (рис.1х) відремонтованими ЦП, що дозволить мінімізувати випадки відсутності необхідних ЦП у складі комплекту ЗІП, якими замінили ті, що відмовили. Такі ситуації трапляються все частіше з причини того, що встановлені терміни експлуатації багатьох об'єктів вже вийшли.

Поповнення ЗІП-О у Збройних силах України проводиться один раз на рік при проведенні ТО-2 за рахунок ЗІП-Г, яким комплектуються об'єкти РЕТ $з$ розрахунку один на п'ять-десять об'єктів. Комплект ЗІП-Г підлягає списанню, а комплект ЗІП-О підлягає списанню тільки зі списанням самого об’єкту. 


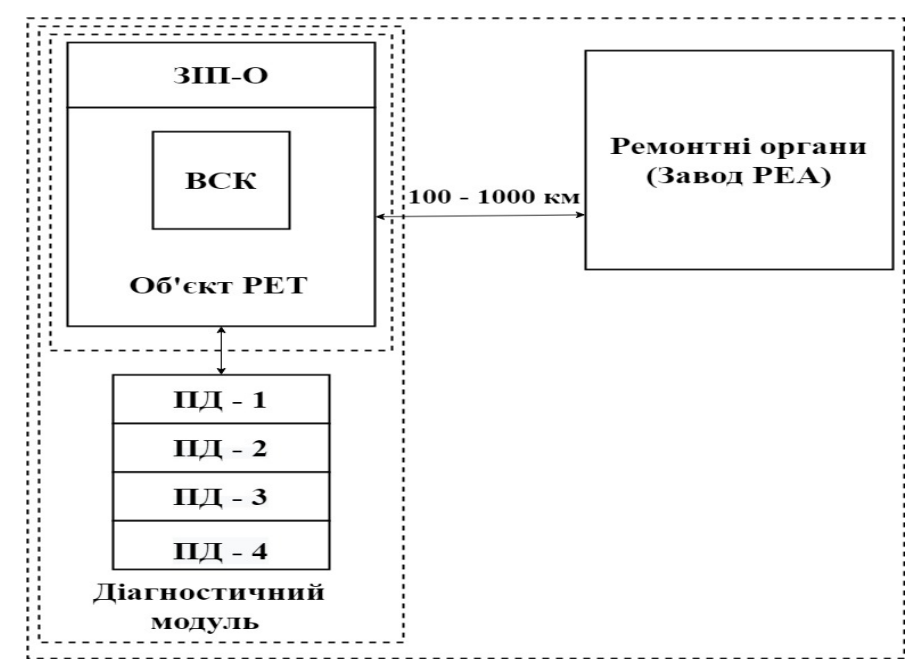

Рис. 1. Структурна схема розташування об’єктів радіоелектронної техніки, пристроїв діагностування та ремонтних органів Джерело: розроблено авторами за даними [1]

Скорочення рис. 1: ВСК - вбудована система контролю, РЕА - радіоелектронна апаратура.

У інших силових структурах, зокрема у Державній службі спеціального зв'язку та захисту інформації, поповнення ЗІП-О проводиться один раз на місяць.

Важливо відмітити і те, що при проведенні перевірок відповідними органами загальна оцінка готовності об'єкта РЕТ знижується, якщо укомплектованість ЗІП складає менше 70\%. Наявність даних фізичного діагностування створює сприятливі умови для планування поповнення ЗІП, що дозволить зменшити середній час відновлення. Зважаючи на зазначені обставини, рішення про визначення міжперевірочного інтервалу може бути адаптивним, тобто не можна вказати його одним і тим же для всіх об'єктів РЕТ, інформація про що має бути записана у базу даних ІСД. Доцільність такого рішення обумовлена ще однією причиною. Дослідження характеру та статистики поступових відмов показало, що кількість їх зростає з часом, що відображає залежність, представлена на рис. 2.

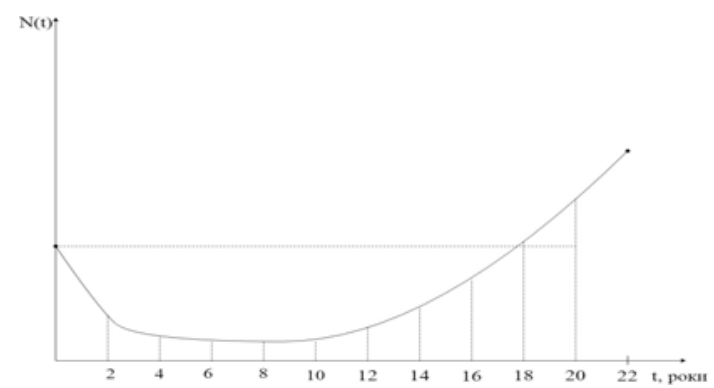

Рис. 2. Залежність кількості відмов цифрових пристроїв від часу експлуатації

Джерело: розроблено авторами за даними [7]

3 огляду на реальні терміни експлуатації, які сьогодні значно перевищили встановлені, все частіше мають прояв відмови РЕК, що обумовлено виродженням кристалів IMC. Такі відмови будуть відбуватися у період часу, коли наробіток буде перевищувати 8-10 років (рис. 2), що характеризується підвищенням значення ДП та відображає виродження кристалів IMC.

Далі стисло розглянемо особливості проведення діагностування та локалізації несправних РЕК зі складу ЦП на об'єкті РЕТ.

Загальний час діагностування ЦП всього об'єкту РЕТ буде залежати від наступних факторів:

1. Кількості ЦП, які підлягають діагностуванню.

2. Кількості ПД.

3. Швидкодії ПД.

4. Кількості ситуацій, пов'язаних 3 неможливістю однозначного прийняття рішення про ТС та потребуючих проведення повторних перевірок одним і тим же ПД або іншими, які є в наявності.

5. ТС самих ПД.

6. Кваліфікації осіб, які проводять діагностику.

7. Кількості осіб, які проводять діагностику.

Дані кількості ЦП свідчать про те, що такий об'єкт РЕТ як радіолокаційна станція, містить 150200 ЦП. Час діагностування одного ЦП одним ПД у випадку однозначного прийняття рішення про справний ТС, складає від двох до трьох хвилин. Розрахунок показує, що час діагностування всіх ЦП одного об'єкта РЕТ за допомогою одного ПД складає від 5 до 10 годин. При цьому вірогідність діагностування складає в залежності від кількості методів, які застосовуються, від 0,95 до 0,97. Одночасне (паралельне) використання трьох ПД призведе до скорочення часу діагностування у 2-3 рази, а послідовне використання трьох ПД збільшить середній час діа- 
гностування, але призведе до збільшення вірогідності діагнозу до 0,99995 .

На рис. 3 представлений діагностичний модуль, який складається 3 трьох ПД та пристрою локалізації, а також генераторів тестових послідовностей, кожний $з$ яких генерує тестову послідовність, яка відповідає методу діагностування. Гнізда для підк- лючення ЦП зображені прямокутниками 3 колами. Для здійснення локалізації несправного РЕК використовуються сигнали, які генерує генератор тестової послідовності для ПД-3, оскільки в його роботі та роботі ПД-4 використовується електромагнітний метод діагностування. Таким модулем пропонується забезпечити перший рівень СТОIР.

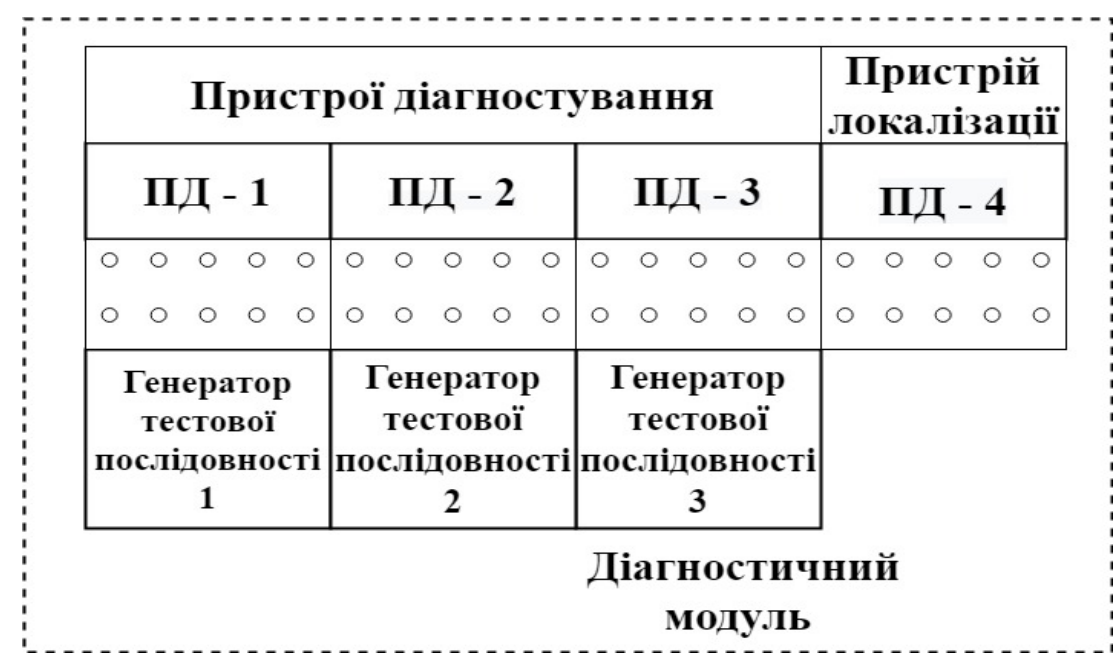

Рис. 3. Діагностичний модуль для здійснення фізичного діагностування Джерело: розроблено авторами за даними [7]

Зважаючи на терміни експлуатації багатьох зразків РЕТ, які перевищили встановлені, кількість поступових відмов буде збільшуватись.

Для упередження таких відмов приймається декілька рішень.

Одне з них полягає у скороченні міжперевірочного інтервалу, тобто діагностування треба буде проводити частіше. Формула для розрахунку міжперевірочного часу була представлена у роботах [13$14]$.

На сьогоднішній день, як правило, детальні регламентні роботи проводяться один раз на півроку, тобто під час проведення сезонного обслуговування. Використання методів фізичного діагностування дозволить прогнозувати і планувати терміни проведення наступних регламентних робіт без прив'язки до планового технічного обслуговування, але до моменту виникнення поступової відмови, що, позитивно вплине на час відновлення i, в цілому, на Кг об'єкта. Як варіант, при зазначених термінах експлуатації діагностування можна проводити щоквартально.

Зважаючи на фактор збільшення відмов 3 часом, для підвищення ймовірності їх упередження пропонується зменшити міжперевірочний інтервал, графік якого представлений на рис. 4.

3 рис. 4 видно, що міжперевірочний інтервал у період нормальної експлуатації є однаковим, оскільки у цей час інтенсивність відмов є постійною. Піс- ля восьмого-десятого року, що залежить від об'єктів PET, умов їх експлуатації, міжперевірочний інтервал має зменшуватись за лінійним законом. Визначення нахилу прямої ділянки графіку проводиться для кожного об'єкта індивідуально та може корегуватися в процесі експлуатації ІСД з метою максимального упередження відмов.

Результати роботи дозволили розробити методику діагностування ЦП об'єктів РЕТ з використанням методів фізичного діагностування.

Методика діагностування цифрових пристроїв об'сктів РЕТ з використанням методів фізичного діагностування.

I. Призначення.

Методика призначена для діагностування ЦП об'єктів РЕТ методами фізичного діагностування при заданій вірогідності та визначеному часі.

Відрізняється від відомих:

- можливістю комплексного застосування методів діагностування, що збільшує вірогідність діагнозу;

- глибиною діагностування на рівні ЦП та не відновлювального елементу;

- отримання результатів фізичного стану напівпровідникових елементів на рівні не відновлювального елементу;

- використанням ІСД для реалізації (автоматизаціі) процесу діагностування. 


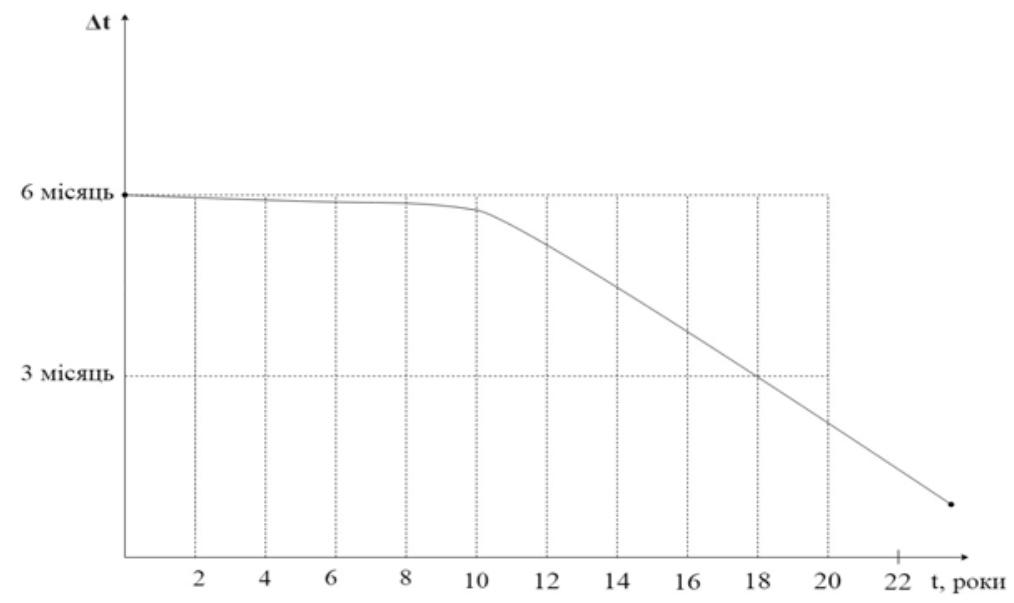

Рис. 4. Залежність міжперевірочного інтервалу від часу експлуатації

Джерело: розроблено авторами

\section{II. Вихідні дані:} вання;

- припустиме значення вірогідності діагносту-

- мінімальні та максимальні допустимі значення ДП;.

- припустимий час діагностування.

Вихідні дані одержують із ЕОМ (перший рівень СТОіР) та бази даних ICД (другий рівень СТОiP).

\section{III. Обмеження:}

- методика застосовується для діагностування цифрових пристроїв об'єктів РЕТ;

- діагностування здійснюється для цифрових пристроїв та РЕК.

IV. Математичний апарат.

У даній методиці використовуються діагностичні моделі цифрових пристроїв, що приведені y [12].

V. Ефект від впровадження.

Ефект від впровадження методики полягає у підвищенні вірогідності діагнозу від 0,95 до 0,99995 (у випадку застосування трьох методів), в скороченні часу діагностування від 2 до 3 разів за рахунок використання трьох пристроїв діагностування, збільшенні середнього часу наробітку на відмову за рахунок завчасної заміни ЦП блоків РЕТ з критичними характеристиками.

VI. Алгоритм реалізації.

Алгоритм реалізації методики діагностування цифрових пристроїв об'єктів радіоелектронної техніки з використанням методів фізичного діагностування представлений на рис. 5 , де $\mathrm{P}-$ вірогідність оцінки технічного стану цифрового пристрою.

\section{Висновки}

1. У статті показано, що для вирішення проблеми надійності радіоелектронної техніки, яка 3 економічних причин експлуатується понад призна- чені терміни, доцільно використовувати методи фізичного діагностування з результатами форсованих випробувань радіоелектронних компонентів на надійність.

2. Для зменшення часу відновлення та збільшення ймовірності укомплектованості комплекту запасних інструментів та приладдя запропоноване проведення діагностування та поточного ремонту цифрових пристроїв на місці знаходження об’єкту. 3 цієї причини запропоновано його оснащення пристроєм локалізації несправних радіоелектронних компонентів зі складу цифрового пристрою.

3. Запропоновано зменшення міжперевірочного інтервалу в залежності від часу експлуатації та надана рекомендація щодо його розрахунку.

4. Представлена методика діагностування цифрових пристроїв з використанням методів фізичного діагностування та алгоритм реалізації методики діагностування цифрових пристроїв об'єктів радіоелектронної техніки з використанням методів фізичного діагностування.

5. Представлену методику діагностування цифрових пристроїв доцільно використовувати для роботи інтелектуальної системи діагностики, що дозволить автоматизувати процеси діагностування, локалізації дефектних радіоелектронних компонентів та проводити прогнозування технічного стану цифрових пристроїв, а також корегувати залежності діагностичного параметру від часу, отримані під час проведення форсованих випробувань радіоелектронних компонентів на надійність.

В подальшому це позитивно вплине на вірогідність діагнозу та прогнозу технічного стану зазначених пристроїв та всього об’єкту радіоелектронної техніки. 


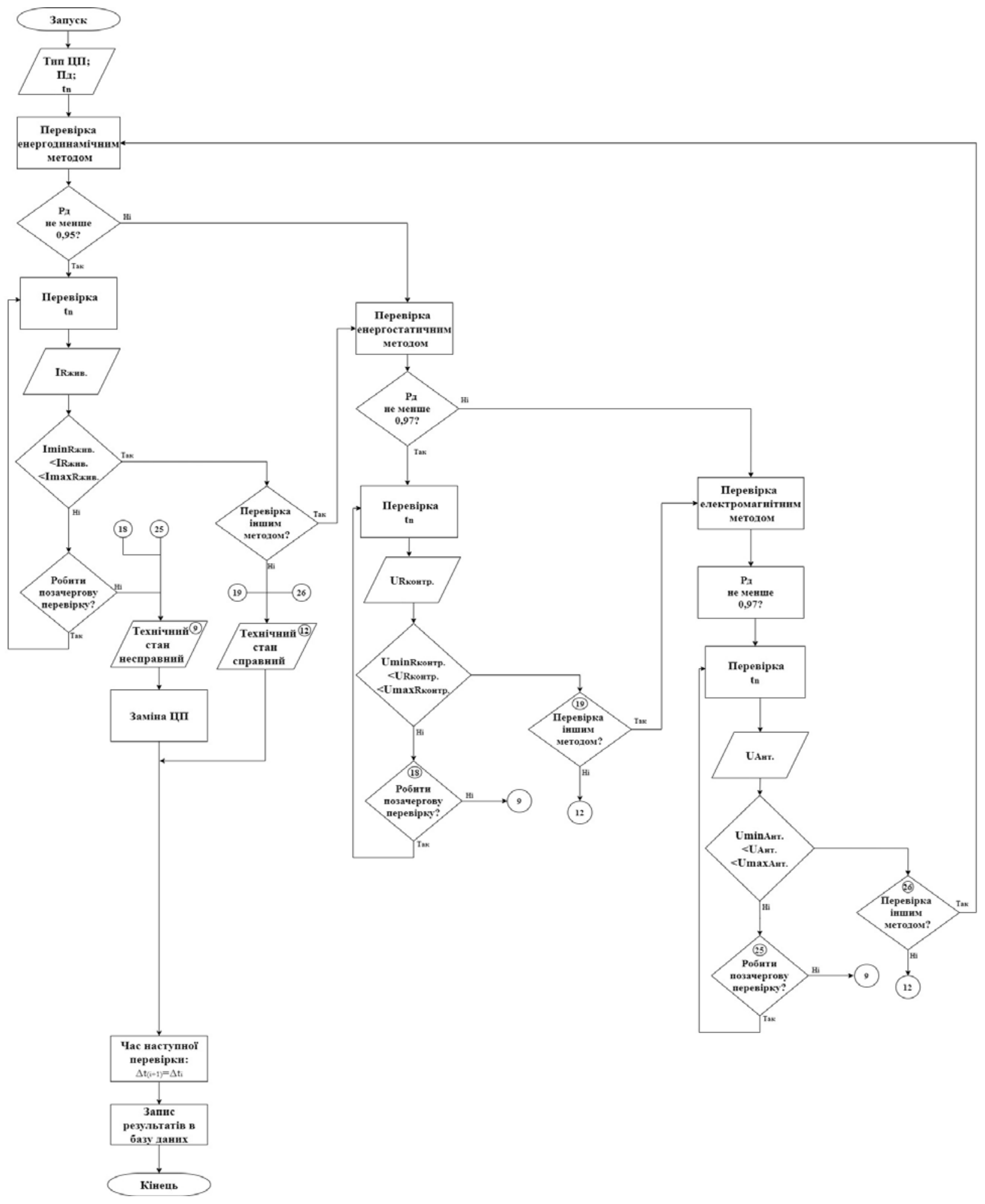

Рис. 5. Алгоритм реалізації методики діагностування цифрових пристроїв об'єктів радіоелектронної техніки з використанням методів фізичного діагностування Джерело: розроблено авторами

\section{Список літератури}

1. Основи теорії надійності та експлуатації радіоелектронних систем / В.І. Василишин, С.В. Женжера, О.В. Чечуй, А.П. Глушко. - Х.: ХНУПС, 2018. - 268 с.

2. Діагностування аналогових і цифрових пристроїв радіоелектронної техніки: монографія / В.В. Вишнівський, М.К. Жердєв, С.В. Лєнков, В.А. Проценко. - К.: ТОВ “Компанія ЛІК”, 2009. - 224 с. 
3. Жердєв М.К. Побудова функціональних перевіряючих тестів для енергодинамічного та електромагнітного методів діагностування / М.К. Жердєв, С.В. Лєнков, П.А. Шкуліпа // Системи обробки інформації. - 2013. - № 1(108). - С. 49-52.

4. Алгоритм побудови тестів діагностування об'єктів радіоелектронної техніки для енергодинамічного і електромагнітного методів / П.А. Шкуліпа, С.В. Лєнков, О.В. Сєлюков, М.М. Охрамович // Вестник научных трудов Восточноукраинского национального университета им. В. Даля. - 2012. - № 12(183). - С. 201-208.

5. Глухов С.І. Діагностування цифрових радіоелектронних компонентів типових елементів заміни радіоелектронної техніки з використанням електромагнітного методу у військових ремонтних органах / С.І. Глухов // Збірник наукових праць Військового інституту Київського національного університету ім. Т. Шевченка. - 2009. - № 21. - С. 42-45.

6. Методика розробки діагностичного забезпечення радіоелектронної техніки на основі енергостатичного методу діагностування з використанням інформаційних технологій / С.В. Лєнков, М.К. Жердєв, І.В. Толок, С.І. Глухов, Г.Б. Жиров // Системи озброєння і військова техніка. - 2017. - № 4(52). - С. 46-51.

7. Діагностування радіоелектронної техніки на основі енергодинамічного методу: методика та інформаційне забезпечення / М.К. Жердєв, О.В. Селюков, С.І. Глухов, С.В. Гахович, М.М. Нікіфоров // Системи озброєння і військова техніка. - 2018. - № 2(54). - С. 23-30.

8. Глухов С.І. Узагальнення результатів форсованих випробувань радіоелектронних компонентів / C.I. Глухов, М.К. Жердєв, В.І. Кузавков // Збірник наукових праць Військового інституту Київського національного університету ім. Т. Шевченка. - 2015. - № 49. - С. 40-48.

9. Вишнівський В.В. Аналіз методів форсованих випробувань для отримання залежності зміни діагностичного параметра від часу напрацювання напівпровідникових РЕК / В.В. Вишнівський, В.В. Кузавков, В.В. Василенко // Системи управління, навігації та зв'язку. - 2015. - № 1. - С. 18-20.

10. Глухов С.І. Особливості використання фізичного діагностування при побудові інтелектуальної системи діагностики радіоелектронної техніки / С.І. Глухов, В.В. Вишнівський, К.П. Сторчак // Загальногалузевий науково-виробничий журнал “Зв'язок”. - 2019. - № 1. - С. 8-13.

11. Глухов С.І. Прогнозування залишкового ресурсу інформаційних систем з використанням інтелектуальної системи діагностування / С.І. Глухов, В.Б. Толубко, В.В. Вишнівський // Наукові записки Українського науково-дослідного інституту зв'язку . - 2019. - № 3(55). - С. 5-11.

12. Математичні моделі та алгоритм обробки діагностичної інформації для побудови інтелектуальної системи діагностування радіоелектронної техніки / В.Б. Толубко, В.В. Вишнівський, С.І. Глухов, Ю.В. Березовська // Наукові записки Університету новітніх технологій. - 2019. - № 4(56). - С. 5-13.

13. Глухов С.І. Обгрунтування вибору інтервалу прогнозування при використанні методів фізичного діагностування для цифрових пристроїв радіоелектронної техніки / С.І. Глухов // Збірник наукових праць Університету новітніх технологій. - 2019. - № 1(8). - С. 151-157.

14. Глухов С.І. Побудова алгоритму розрахунку часу прогнозування технічного стану цифрових пристроїв радіоелектронної техніки при використанні методів фізичного діагностування / С.І. Глухов // Системи озброєння і військова техніка. - 2019. - № 1(57). - С. 69-76.

\section{References}

1. Vasilishin, V.I., Chechui, O.V., Zhenzera, S.V. and Glushko, A.P. (2018), “Osnovi teoriyi nadijnosti ta ekspluataciyi radioelektronnih sistem" [Fundamentals of the theory of reliability and operation of radio electronic systems], KNUPS, Kharkiv, $268 \mathrm{p}$.

2. Vishnivsky, V.V., Zherdiev, M.K., Lenkov, S.V. and Protsenko, V.A. (2009), "Diagnostuvannya analogovih i cifrovih pristroyiv radioelektronnoyi tehniki" [Diagnosis of analog and digital devices of electronic equipment], LLC "Company LIK", Kyiv, 224 p.

3. Zherdev, M.K., Lenkov, S.V. and Shkulipa, P.A. (2013), "Pobudova funkcionalnih pereviryayuchih testiv dlya energodinamichnogo ta elektromagnitnogo metodiv diagnostuvannya" [Construction of functional checking tests for energy dynamical and electromagnetic methods of diagnostics], Information Processing Systems, No. 1(108), pp. 49-52.

4. Shkulipa, P.A., Ljenkov, S.V., Sjeljukov, O.V. and Ohramovych, M.M. (2012), "Algorytm pobudovy testiv diagnostuvannja ob'jektiv radioelektronnoi' tehniky dlja energodynamichnogo i elektromagnitnogo metodiv" [The algorithm for constructing objects diagnostics tests for radio-electronic equipment and electromagnetic methods enerhodynamichnoho], Bulletin of scientific works of V. Dahl East Ukrainian National University, No. 12(183), pp. 201-208.

5. Hlukhov, S.I. (2009), "Diahnostuvannia tsyfrovykh radioelektronnykh komponentiv typovykh elementiv zaminy radioelektronnoi tekhniky z vykorystanniam elektromahnitnoho metodu u vijs'kovykh remontnykh orhanakh" [Diagnosticating of digital radio electronic components of typical elements of replacement of radio electronic technique is with the use of electromagnetic method in soldiery repair organs], Collection of scientific works of the Military Institute of Kyiv National University named after T. Shevchenko, No. 21, pp. 42-45.

6. Ljenkov, S.V., Zherdjev, M.K., Tolok, I.V., Gluhov, S.I. and Zhyrov, G.B. (2017), "Metodyka rozrobky diagnostychnogo zabezpechennja radioelektronnoi' tehniky na osnovi energostatychnogo metodu diagnostuvannja $\mathrm{Z}$ vykorystannjam informacijnyh tehnologij" [Methods of developing diagnostic software for electronic equipment based on the energy-static method of diagnosing using information technology], Systems of Arms and Military Equipment, No. 4(52), pp. 46-51.

7. Zherdjev, M.K., Seljukov, O.V., Gluhov, S.I., Gahovych, S.V. and Nikiforov, M.M. (2018), "Diagnostuvannja 
radioelektronnoi' tehniky na osnovi energodynamichnogo metodu: metodyka ta informacijne zabezpechennja" [Diagnosis of electronic equipment on the basis of energy-dynamic method: methods and information support], Systems of Arms and Military Equipment, No. 2(54), pp. 23-30.

8. Zherdiev, M.K., Kuzavkov, V.V. and Hlukhov, S.I. (2015), "Uzahal'nennia rezul'tativ forsovanykh vyprobuvan' radioelektronnykh komponentiv" [Summary of results of the forced test of radio-electronic components], Collection of scientific works of the Military Institute of Kyiv National University named after T. Shevchenko, No. 49, pp. 40-48.

9. Vyshnivs'kyj, V.V., Kuzavkov, V.V. and Vasylenko, V.V. (2015), “Analiz metodiv forsovanyh vyprobuvan' dlja otrymannja zalezhnosti zminy diagnostychnogo parametra vid chasu napracjuvannja napivprovidnykovyh REK” [Control, navigation and communication systems], Control, navigation and communication systems, No. 1, pp. 18-20.

10. Gluhov, S.I., Vyshnivs'kyj, V.V. and Storchak, K.P. (2019), “Osoblyvosti vykorystannja fizychnogo diagnostuvannja pry pobudovi intelektual'noi' systemy diagnostyky radioelektronnoi' tehniky" [Features of the use of physical diagnostics in the construction of an intelligent system for diagnostics of electronic equipment], General industry research and production journal "Communication", No. 1, pp. 8-13.

11. Gluhov, S.I., Tolubko, V.B., Vyshnivs'kyj, V.V. and Gluhov, S.I. (2019), "Prognozuvannja zalyshkovogo resursu informacijnyh system z vykorystannjam intelektual'noi' systemy diagnostuvannja" [Forecasting the residual resource of information systems using an intelligent diagnostic system], Scientific notes of the Ukrainian Research Institute of Communications, No. 3(55), pp. 5-11.

12. Gluhov, S.I., Tolubko, V.B., Vyshnivs'kyj, V.V. and Berezovs'ka, Ju.V. (2019), "Matematychni modeli ta algorytm obrobky diagnostychnoi' informacii' dlja pobudovy intelektual'noi' systemy diagnostuvannja radioelektronnoi' tehniky" [Mathematical models and algorithm for processing diagnostic information for building an intelligent system for diagnosing electronic equipment], Scientific notes of the Ukrainian Research Institute of Communications, No. 4(56), pp. 5-13.

13. Gluhov, S.I. (2019), “Obgruntuvannja vyboru intervalu prognozuvannja pry vykorystanni metodiv fizychnogo diagnostuvannja dlja cyfrovyh prystroi'v radioelektronnoi' tehniky" [Rationale for the choice of forecasting interval when using physical diagnostic methods for digital devices of electronic equipment], Scientific notes of the Ukrainian Research Institute of Communications, No. 1(8), pp. 151-157.

14. Gluhov, S.I. (2019), "Pobudova algorytmu rozrahunku chasu prognozuvannja tehnichnogo stanu cyfrovyh prystroi'v radioelektronnoi' tehniky pry vykorystanni metodiv fizychnogo diagnostuvannja" [Construction of algorithm for calculating the time of forecasting the technical condition of digital devices of electronic equipment using physical diagnostic methods], Systems of Arms and Military Equipment, No. 1(57), pp. 69-76.

\section{Відомості про авторів:}

\section{Сакович Лев Миколайович}

кандидат технічних наук доцент доцент кафедри Національного технічного університету України “Київський політехнічний інститут ім. І. Сікорського",

Київ, Україна

https://orcid.org/0000-0002-8257-7086

\section{Глухов Сергій Іванович}

кандидат технічних наук доцент

завідувач кафедри

факультету післядипломної освіти

Київського національного університету

ім. Т. Шевченка,

Київ, Україна

https://orcid.org/0000-0002-4918-3739

\section{Бабій Олександр Сергійович}

старший викладач кафедри

військово-технічної підготовки факультету

післядипломної освіти

Київського національного

університету ім. Т. Шевченка,

Київ, Україна

https://orcid.org/0000-0001-5752-5025

\section{Information about the authors:}

\author{
Lev Sakovych \\ Candidate of Technical Sciences \\ Associate Professor \\ of the Department of Institute of National \\ University of Ukraine "KPI", \\ Kyiv, Ukraine \\ https://orcid.org/0000-0002-8257-7086
}

\section{Sergey Glukhov}

Candidate of Technical Sciences Associate Professor

Head of the Department

of the Faculty of Postgraduate Education

of the Military Institute of Taras Shevchenko

Kyiv National University,

Kyiv, Ukraine

https://orcid.org/0000-0002-4918-3739

\author{
Alexander Babiy \\ Senior Instructor \\ of the Department of the Faculty \\ of Postgraduate Education \\ of the Military Institute of Taras Shevchenko \\ Kyiv National University, \\ Kyiv, Ukraine \\ https://orcid.org/0000-0001-5752-5025
}


Гальоса Андрій Олександрович студент Коледжу інженерії та управління Національного Авіаційного Університету, Київ, Україна https://orcid.org/0000-0002-7791-5458

\section{Andrey Halosa}

Student of the College of Engineering and Management of the National Aviation University, Kyiv, Ukraine https://orcid.org/0000-0002-7791-5458

\title{
МЕТОДИКА ФИЗИЧЕСКОГО ДИАГНОСТИРОВАНИЯ ЦИФРОВЫХ УСТРОЙСТВ ОБЪЕКТОВ РАДИОЭЛЕКТРОННОЙ ТЕХНИКИ
}

\author{
Л.Н. Сакович, С.И. Глухов, А.С. Бабий, А.А. Галёса
}

В статье представлена методика физического диагностирования цифровых устройств объектов радиоэлектронной техники, которая основывается на использовании энергодинамического, энергостатического и электромагнитного методов диагностирования. Она предусматривает одиночное или комплексное применение данных методов, что зависит от требуемой достоверности диагноза. Последняя определяется значимостью объекта радиоэлектронной техники, а также случаями, когда невозможно принять решение о техническом состоянии при использовании какого-нибудь одного метода диагностирования. Использование данной методики физического диагностирования ичифровых устройств блоков объектов радиоэлектронной техники направлено на определение технического состояния с достоверностью не ниже 0,95, а ее применение на первом уровне системь технического обслуживания и ремонта радиоэлектронной техники позволит проводить определение реального технического состояния при глубине диагностирования ицифровых устройств (радиоэлектронного компонента), что приведет к уменьшению логистической составляющей доставки ичирровых устройств в ремонтные органы и в обратном направлении. Применение данной методики ияелесообразно в работе автоматизированной системы технической диагностики радиоэлектронной техники.

ключевые слова: радиоэлектронная техника, ичифровые устройства, радиоэлектронные компоненты, техническое состояние, прогнозирование, интеллектуальная система диагностики.

\section{PHYSICAL DIAGNOSIS TECHNIQUE OF RADIOELECTRONIC EQUIPMENT DIGITAL DEVICES}

\section{Sakovych, S. Hlukhov, O. Babii, A. Halosa}

The article presents a physical diagnosis technique of radio-electronic equipment digital devices based on the use of energy-dynamic, energy-static and electromagnetic methods of diagnosis. The technique provides for a single or combined application of the mentioned methods, depending on the required diagnosis credibility. The latter stems from the importance of the radio-electronic equipment item, as well as cases in which it is impossible to decide on the technical state when using any one of the diagnosis methods. The credibility of diagnosis when determining and forecasting the technical state may be increased by the combined use of the mentioned methods and extreme reliability tests results which are the time dependencies of a diagnostic parameter for each diagnosis method and are used as a reference. These dependencies are recorded in the Intelligent Diagnosis System database which is a second-level component of radio-electronics' Maintenance and Repair System. The use of a physical diagnosis technique of radio-electronic equipment digital devices is aimed to define technical state at the credible level that is not below 0.95. The technique's application at the first level of the radio-electronics' Maintenance and Repair System shall allow determining the real technical state at the depth of digital device (radio-electronic component) diagnosis, resulting in the decrease of the logistic component of digital devices delivery to repair units and vice versa. It is advisable to use this technique in the operation of the radio-electronics' Technical Diagnosis Automated System, enabling preventing failures of digital devices with critical characteristics with a high probability and extending service-life of blocks by timely replacement of their components. Application of this method will allow to increase the average time to failure, reduce the mean time to recover and increase the key reliability indicator - availability factor of the radio-electronics.

Keywords: radio-electronics, digital devices, radio-electronic components, technical state, forecasting, Intelligent Diagnosis System. 